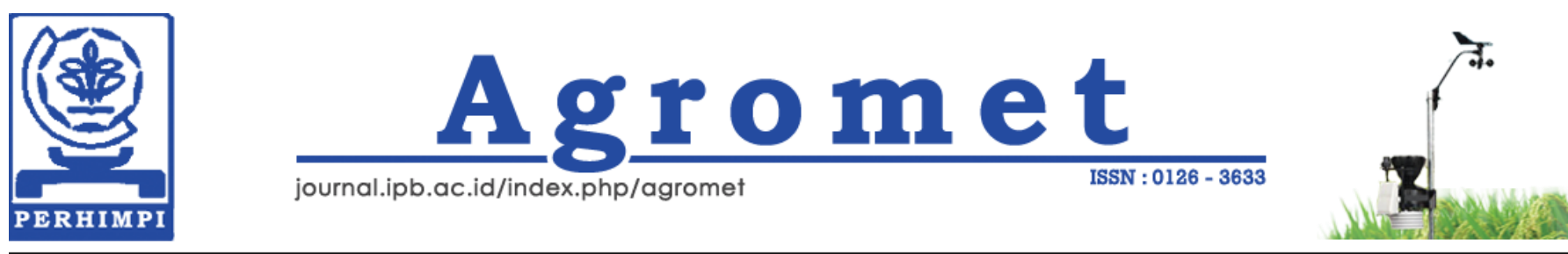

\title{
Drought Events in Western Part of Timor Island Indonesia
}

\section{Flegor Hermes Sabuna, Rini Hidayati, I Putu Santikayasa, Muh Taufik}

Department of Geophysics and Meteorology, Faculty of Mathematics and Natural Sciences, IPB University, Dramaga Campus, Bogor, Indonesia 16680

\section{ARTICLE INFO}

\section{Received}

2 September 2021

\section{Revised}

1 December 2021

\section{Accepted for Publication}

10 December 2021

\section{Published}

11 February 2022

doi: 10.29244/j.agromet.36.1.11-20

\section{Correspondence: \\ Rini Hidayati \\ Department of Geophysics and Meteorology, Faculty of Mathematics and Natural Sciences, IPB University, Dramaga Campus, Bogor, Indonesia 16680 \\ Email: rinihidayati@apps.ipb.ac.id}

This is an open-access article distributed under the CC BY License. (c) 2022 The Authors. Agromet.

\begin{abstract}
A B S T R A C T
Drought is a below-averaged condition of water availability, which has detrimental impacts on many sectors. Many studies have been performed on drought analysis in Indonesia, yet knowledge about drought in western Timor is still limited. This research carried out a historical meteorological drought analysis based on a 3-month Standardized Precipitation Index (SPI) and Standardized Precipitation Evapotranspiration Index (SPEI) using global climate data for 1989-2018. The index value was then categorized into three groups: moderate, severe, and extreme. We assessed: (i) the influence of EI Niño phenomena to drought events, (ii) drought class frequency, and (iii) drought trend. Based on historical data, western Timor had a monsoonal pattern with dominant dry period, which occurred in April to November. The results showed that the drought events were mostly influenced by El Niño. Seasonally, El Niño not only increased the drought frequency in July-August (JJA) season, but also in other seasons. In El Niño year of 2015, drought covered most parts of study area during September-November (SON) season, especially in the western part. Dry conditions increased in June, reached maximum in September-November, and decreased in December. Other findings show that an extreme drought consistently had a downtrend, while the moderate drought had upward trends. Spatiotemporal drought analysis using SPI and SPEI showed similar patterns, SPEI detected a higher frequency of drought classes compared to SPI. This study suggests that knowledge on drought-related El Niño will benefit on drought mitigation action in the future.
\end{abstract}

\section{KEYWORDS}

drought frequency, El Niño, meteorological drought, rainfall pattern, trend

\section{INTRODUCTION}

Drought is a below-averaged water availability from its normal condition. Drought has detrimental impacts on many sectors, including agriculture (Nath et al., 2017; Surmaini et al., 2018), environment (Russo et al., 2017; Taufik et al., 2017), and economy (Edwards et al., 2019; Kang et al., 2019). Based on its character, drought can be classified into three categories, namely meteorological, hydrological, and agricultural drought (Van Loon, 2015). Meteorological drought is caused by a decreased rainfall over a certain time. Agricultural drought is defined as a condition when the lack of rainfall causes soil moisture deficit leading to crop failure. Meanwhile, hydrological drought occurs when surface water and groundwater resources are limited due to a prolonged dry season. Another drought category is related to its impact on society, which is called socioeconomic drought (Guo et al., 2019; Liu et al., 2020).

Many studies have been performed to analyze drought in Indonesia (Ferijal et al., 2021; Lestari et al., 2018; Surmaini et al., 2019; Tallar and Dhian, 2021). Yet, drought research in western Timor is still limited. Western Timor is part of East Nusa Tenggara province, which is classified as a type $D$ in climatic zone according to Oldeman climate classification. Type D climate 
represents a more dry season (8-9 months) within a year. This condition combined with drought phenomena due to global climate variability, such as El Niño, could cause severe drought (Nguyen et al., 2021; Pan et al., 2018; Singh and Shukla, 2020; Taufik et al., 2020), which leads to water scarcity (Guimarães Nobre et al., 2019; Williamson, 2020). To prevent various problems triggered by drought, knowledge about the historical pattern of drought phenomena is important.

The spatiotemporal analysis provides deep information both in the spatial and temporal sense. In drought analysis, it can be done by integrating spatial climate data and drought index. There are numerous drought indices have been developed worldwide, for example, are Standardized Precipitation Index (SPI) and Standardized Precipitation Evapotranspiration Index (SPEI). Both indices are widely-used to monitor drought due to their simplicity (Bhunia et al., 2020; Danandeh Mehr and Vaheddoost, 2020; Tefera et al., 2019; Y. Wang et al., 2019). The SPI only uses the rainfall variable as an input, while SPEI employs the difference between rainfall and evapotranspiration represented as a climatic water balance condition. Another similarity is the indices are usually calculated using input data on a monthly scale, and result in drought indices in various time scales, such as $1,3,6,12,24$, or 48 months.

In this research, we combine the global climate dataset with those two drought indices (SPI and SPEI) to analyze the historical pattern of drought phenomena in western Timor. In specific, this research aims to: (i) calculate the frequency of drought events based on index value, (ii) analyze the influence of $\mathrm{El} \mathrm{Niño}$ phenomena on drought events in western Timor, and (iii) determine the trend of drought class over the period 1989-2018. The results are expected to be a reference in developing plans for drought mitigation action in the future.

\section{RESEARCH METHODS}

\section{Data Source}

The study area is in the western part of Timor Island (Figure 1a). The elevation is varied from zero to more than 2,000 meters. The highest place (2,233 m.asl) is Mutis mountain located in the middle of western Timor.

For drought analysis, there are two climate variables used in this research, i.e. rainfall and air temperature. Spatial air temperature data was obtained from reanalysis data of ERA Interim produced by the European Centre for Medium-Range Weather Forecasts (ECMWF, www.ecmwf.int/). Meanwhile, rainfall data was an estimated rainfall data developed by the Center for Hydrometeorology and Remote Sensing (CHRS, chrsdata.eng.uci.edu). Both climate data have a spatial resolution of $0.25^{\circ}$ and cover the period from 1989 2018.

To compare drought events with global climate variability, we used data of El-Nino events as indicated by Southern Oscillation Index (SOI) during the analysis period. It was obtained from the Bureau of Meteorology Government (bom.gov.au). This index was calculated based on the pressure differences between Tahiti and Darwin. El Niño event was shown as an index value less than -7 . In this research, all analyses were performed by using the $\mathrm{R}$ language program ( $\mathrm{R}$ Core Team, 2021).

\section{Drought Identification}

In this research, we identified drought events based on standardized indices. Specifically, we compare two widely-used drought indicators, namely the Standardized Precipitation Index (SPI; McKee et al., 1993) and Standardized Precipitation Evapotranspiration Index (SPEI; Vicente-Serrano et al., 2010). These indices used a similar approach, yet with different input data. The SPI used only the rainfall variable, whereas the SPEI employed a simple climatology water balance derived from the difference between rainfall and potential evapotranspiration (ETp).

These standardized indices determine anomalies at a specific location based on a comparison of variable value over a certain period (e.g. 1, 3, 6, 12, 24 months) with the long-term (usually more than 30 years) historical data. The data is then fitted to a probabilistic distribution and transformed into a normal distribution. Here, we used gamma distribution for the historical data distribution, since it gave a good result for monthly analysis (Shiau, 2020; Svensson et al., 2017; H. Wang et al., 2019; Wang et al., 2021). From the various time scales, we only selected 3-months in a row for both SPI and SPEI analysis as its good result for seasonal analysis (Gidey et al., 2018). In general, the index value can be classified into three categories, which are drought (less than 1), normal (between -1 to 1), and wet (more than 1).

\section{Potential Evapotranspiration Calculation}

To calculate SPEI, we firstly determined the monthly potential evapotranspiration (ETp) data based on air temperature. This research used the Thornthwaite method (Thornthwaite, 1948) since it is the simplest and most general to calculate monthly potential evapotranspiration (Trajkovic et al., 2019). Thornthwaite's equation only used average daily air temperature representing meteorological conditions (Equation 1). The output ETp is in cumulative $\mathrm{mm} /$ month. 

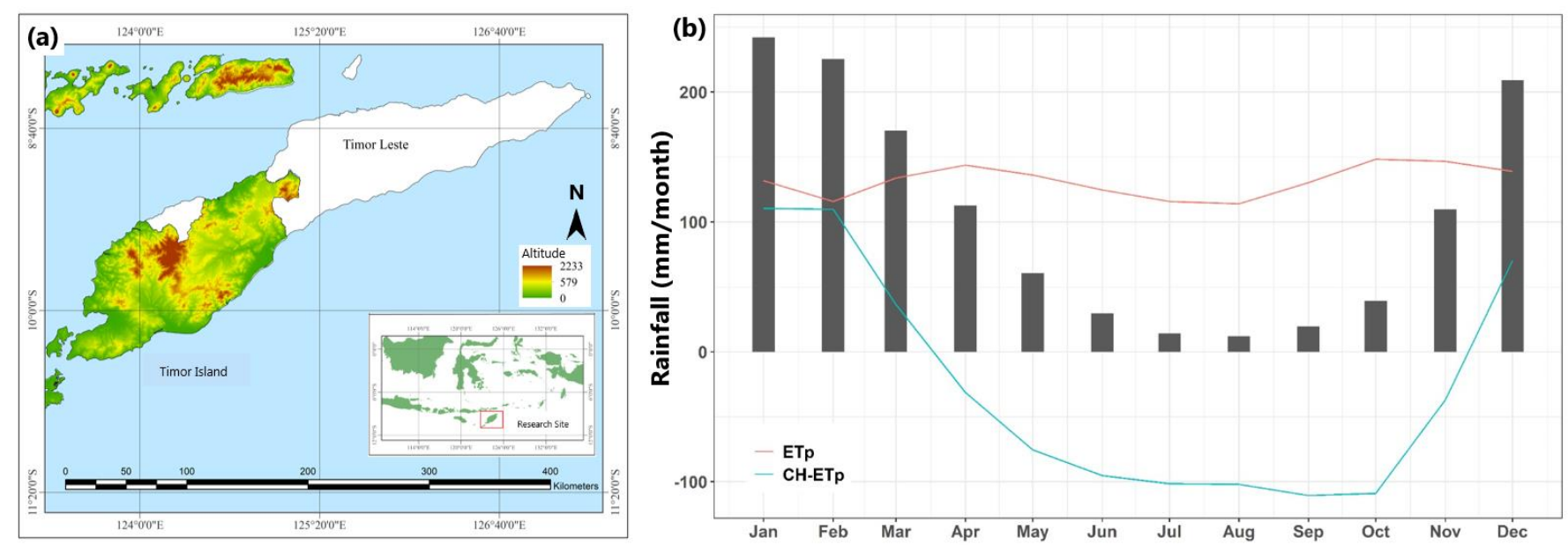

Figure 1. (a) Study site location. (b) Monthly pattern of rainfall (bar graph), potential evapotranspiration (ETp, red line), and the difference between rainfall and ETp (blue line) in western Timor during the period 1989-2018.

$$
\operatorname{ETp}_{i}=16 \times \frac{L_{i}}{12} \times \frac{N_{i}}{30} \times\left(\frac{10 T}{I}\right)^{a}
$$

where $L$ average daylight (hours), $N$ days in a month, $T$ is monthly air temperature $\left({ }^{\circ} \mathrm{C}\right), I$ and $a$ heat index, and $i$ is monthly timescale. In this calculation, we assumed that daylight in Timor is about 12 hours on average. Variable $I$ is the annual heat index, which is calculated based on Equation 2. Meanwhile, variable $a$ is obtained from Equation 3.

$$
\begin{aligned}
I & =\sum_{\text {Dec }}^{\operatorname{Jan}}\left(\frac{T}{5}\right)^{1.514} \\
a & =6.75 \times 10^{-7} I^{3}-7.71 \times 10^{-3} I^{2}+1.7921 \times \\
10^{-2} I+ & 4.9239 \times 10^{-1}
\end{aligned}
$$

\section{Drought Analysis}

Drought events were identified based on drought index (SPI and SPEI) values. The drought initiates when the index value falls below -1 . Since this research discussed drought distribution, we only focused on drought conditions for further analysis (Table 1). This classification was applied for both indices.

Table 1. The index value classification for drought conditions based on McKee et al. (1993) classification.

\begin{tabular}{cl}
\hline Index score & Drought Class \\
\hline-1.49 to -1.00 & Moderate \\
-2.00 to -1.49 & Severe \\
$\leq-2.00$ & Extreme \\
\hline
\end{tabular}

\section{Frequency Analysis}

Drought frequency was performed in annual and seasonal, which were based on spatiotemporal data of the drought indices. The frequency was determined by calculating the percentage of each class that occurred within the specified timescale analysis (annual or seasonal). Mathematically, the frequency was calculated using Equation 4.

$$
\text { Frequency }=\frac{n_{x}}{N} x 100
$$

where $n$ is the number of events for class $x$, and $N_{i}$ is the total events within a specific timescale analysis (annual or seasonal). For annual analysis, we calculated drought class proportion (in Table 1) each year from 1989-2018. Meanwhile, for seasonal analysis, the calculation only focused on El Niño years, which were in 1991/1992, 1997/1998, 2001/2002, 2006/2007, and 2015/2016.

\section{Trend}

The drought trend was analyzed by a linear regression model for each category. The trend was shown by the gradient value of the line, which is drawn by the regression model. A negative gradient value indicates a downtrend, while the positive one represents an uptrend. This method is the simplest way to detect the shifting of drought events.

\section{RESULTS AND DISCUSSIONS}

\section{The climate condition of Western Timor}

Climate condition was analyzed based on the monthly average of rainfall and potential evapotranspiration (ETp). Based on the monthly pattern, the variability of rainfall in western Timor was higher than evapotranspiration (Figure 1b). The monthly rainfall varied from $10 \mathrm{~mm}$ (in August) to $240 \mathrm{~mm}$ (in January). Meanwhile, the ETp valued at more than $100 \mathrm{~mm}$ for every month, varying between 115 and $150 \mathrm{~mm}$. The lowest ETp occurred in February and August, while the highest was in October. The dynamic of monthly rainfall followed a monsoonal pattern, which had increased rainfall in Dec-Feb, yet low in the middle of the year. 
Specifically, there were six consecutive months, namely May-Oct, identified as the dry month $(\leq 60 \mathrm{~mm})$.

Based on the annual calculation, the accumulated rainfall was $20 \%$ lower than the potential evapotranspiration which was about $1,578 \mathrm{~mm}$. It was confirmed by the water balance throughout the year. There were eight months in a row (Apr-Nov) that had a negative value for its monthly water balance. Two months of that period, namely April and November, were even included as wet months since they had rainfall of more than $100 \mathrm{~mm}$. A negative water balance represents a deficit water condition, which potentially causes drought. This condition depicts the water losses taken by the environment is higher than input from precipitation.

Seasonally, western Timor received the highest rainfall in December-February (DJF) as it had more than $200 \mathrm{~mm}$ on average. From March to May (MAM), the rainfall substantially decreased from above $150 \mathrm{~mm}$ to about $60 \mathrm{~mm}$, which indicated the transitional period to the dry season. In contrast, the rainfall significantly rose during the September-November period (SON). Specifically, rainfall in November was almost three times higher than that of September and October. The June-August period (JJA) was the driest season compared to others. In total, the period only received $55 \mathrm{~mm}$. For potential evapo-transpiration, the transitional season (MAM and SON) resulted in a higher value.

\section{Influence of El Niño on Drought Frequency a. Annual Drought Events}

Annual drought frequency was derived from the amount of data for each class (in Table 1) divided by total data in a year. In general, there is only extreme class that fluctuated in the range of $0-25 \%$.

In SPI analysis, the extreme drought category experienced a high proportion twice, which was coincided with El Niño events (Figure 2a). The highest proportion occurred in 1991/1992 with almost $25 \%$ of the time. The second one was in 1997/1998, which accounted for about $18 \%$. In the last two decades, the extreme class was frequently near $0 \%$. Only in the $\mathrm{El}$ Niño period of 2015/2016 did the class increase up to $3 \%$. The severe drought class varied between 0 and $13 \%$. There were four times that the severe class's proportion was rising. Some periods coincided with El Niño years. The moderate drought class was more fluctuated compared to others. The highest proportion of the class was not in the El Niño period (in 1994 and 2005). Only in 2015 , the moderate class rose gradually up to $17 \%$.

The dynamic of drought class proportion for SPEI was almost similar to SPI (Figure $2 \mathrm{~b}$ ). In the beginning period, the extreme class proportion increased and reached its peak in 1992 at $25 \%$. Its increase coincided with strong El Niño years (1991/1992 period). However, the proportion decreased significantly become $5 \%$ by next year. The next high percentage of extreme class

(a) SPI

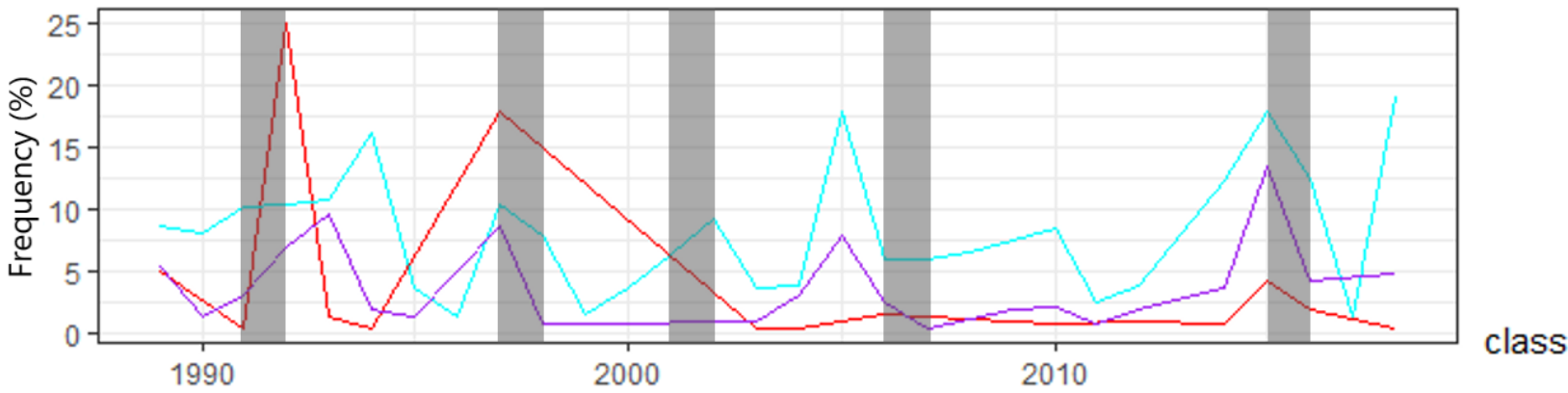

(b) SPEI

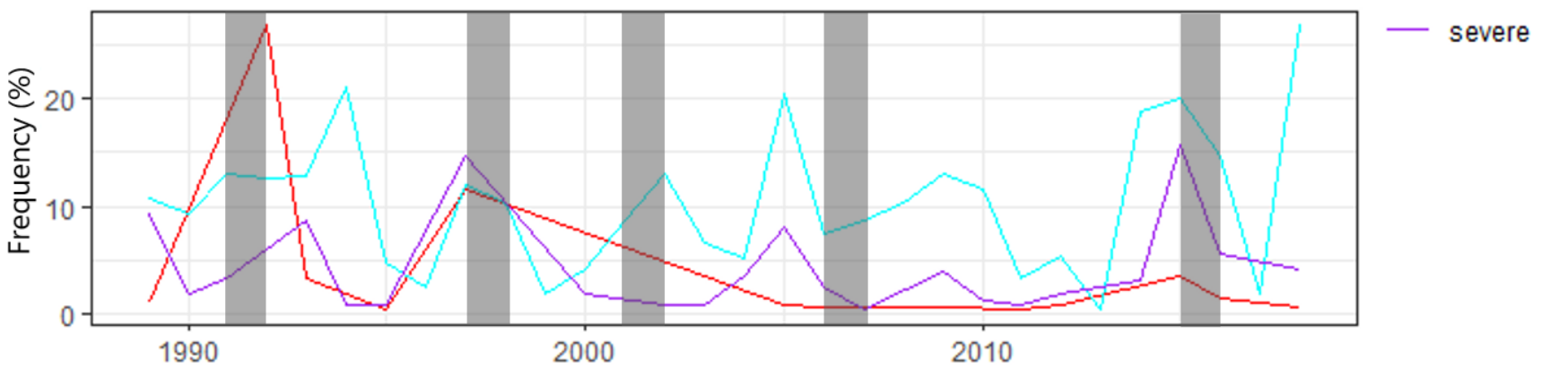

Figure 2. Dynamic of annual drought class proportion based on: (a) Standardized Precipitation Index (SPI) and (b) Standardized Precipitation Evapotranspiration Index (SPEI) in western Timor for the period between 1989 and 2018. The grey highlight denotes El Niño years. 
occurred in the second El Niño year (1997/1998), which went up about $12 \%$. The proportion then declined gradually for the next eight years and slightly increased in 2015. The severe class variability was also higher than that of SPI results, as it was shown in 1997, 2009, and 2015. The proportion went up by about $5 \%$ for each year mentioned. The average percentage of moderate drought class in SPEI was also higher than that of SPI. Yet, the high proportion mostly occurred during the EI Niño years, which were in 1994, 2005, and 2018.

These results indicated that SPEI detected a higher frequency in other classes compared to SPI. The higher drought proportion in SPEI implied the lower standardized index value, which could be due to the influence of the evapotranspiration variable included (Polong et al., 2019; Yao et al., 2020). Furthermore, SPEI was also indirectly influenced by the air temperature variable (Fung et al., 2020; Qutbudin et al., 2019; Sein et al., 2021), since it was used as input data to calculate evapotranspiration. This finding corresponded with several studies reporting that SPEI resulted in a higher drought frequency than SPI (Pei et al., 2020; Potopová et al., 2018).

The annual drought frequency analysis in western Timor showed that the proportion of the change for each class was mostly influenced by El Niño events. It was shown by an increased frequency of the three drought classes (moderate, severe, and extreme) during El Niño events. El Niño is global climate variability, which decreases rainfall in most parts of Indonesia (Hendrawan et al., 2019; Kurniadi et al., 2021; Supari et al., 2018), including Timor. El Niño events then indirectly escalated the drought severity (Cunha et al., 2018; Noorisameleh et al., 2021).

\section{b. Seasonal Drought Events}

The influence of El Niño on drought events was then specifically analyzed in seasonal terms. There were five El Niño periods that we used to calculate the drought frequency of each season, as shown in Table 2. In general, the stronger severity of El Niño not only increased the drought frequency in the JJA season but

During the weak El Niño period, the high drought frequency (moderate, severe, and extreme) occurred out of the JJA season. In the strong El Niño year (1991/1992), even though in the SON season there was no drought events detected by the indices, the drought frequency in DJF and MAM was high, totally more than $65 \%$ and $69 \%$, respectively. The highest drought frequency occurred in the very strong El Niño

Table 2. Frequency of drought index at seasonal scale in western Timor Island during El Niño years (1989-2018). Two indices used were the Standardized Precipitation Index (SPI) and Standardized Precipitation Evapotranspiration Index (SPEI). The three letters in the season column mean the abbreviation of three months in a row: December-February (DJF), March-May (MAM), June-August (JJA), and September-November (SON).

\begin{tabular}{|c|c|c|c|c|c|c|c|}
\hline \multirow{3}{*}{ El Niño Year } & \multirow{3}{*}{ Season } & \multicolumn{6}{|c|}{ Drought Class } \\
\hline & & \multicolumn{3}{|c|}{ SPI } & \multicolumn{3}{|c|}{ SPEI } \\
\hline & & Moderate & Severe & Extreme & Moderate & Severe & Extreme \\
\hline \multirow{4}{*}{$\begin{array}{l}\text { 1991/1992 } \\
\text { (strong) }\end{array}$} & DJF & 21 & 11 & 33 & 23 & 10 & 33 \\
\hline & MAM & 3 & - & 66 & 4 & - & 66 \\
\hline & JJA & 16 & 15 & - & 21 & 13 & 7 \\
\hline & SON & - & - & - & - & - & - \\
\hline \multirow{4}{*}{$\begin{array}{l}1997 / 1998 \\
\text { (very strong) }\end{array}$} & DJF & - & - & - & - & - & - \\
\hline & MAM & - & - & 33 & - & 9 & 23 \\
\hline & JJA & 19 & 21 & 38 & 16 & 41 & 22 \\
\hline & SON & 22 & 13 & - & 30 & 7 & - \\
\hline \multirow{4}{*}{$\begin{array}{l}\text { 2001/2002 } \\
\text { (weak) }\end{array}$} & DJF & 11 & - & - & 16 & - & - \\
\hline & MAM & 23 & 3 & - & 29 & 3 & - \\
\hline & JJA & 1 & - & - & 5 & - & - \\
\hline & SON & - & - & - & - & - & - \\
\hline \multirow{4}{*}{$\begin{array}{l}\text { 2006/2007 } \\
\text { (weak) }\end{array}$} & DJF & 2 & - & - & 3 & - & - \\
\hline & MAM & - & - & - & - & - & - \\
\hline & JJA & - & - & - & - & - & - \\
\hline & SON & 21 & 9 & 5 & 26 & 9 & 2 \\
\hline \multirow{4}{*}{$\begin{array}{l}2015 / 2016 \\
\text { (very strong) }\end{array}$} & DJF & 5 & 9 & 2 & 10 & 9 & - \\
\hline & MAM & 13 & - & - & 15 & - & - \\
\hline & JJA & 20 & 2 & - & 25 & 6 & - \\
\hline & SON & 32 & 41 & 14 & 28 & 47 & 14 \\
\hline
\end{tabular}


period. In the1997/1998 period, drought was strongly identified in JJA season as its proportion covered about $78 \%$ in total. For MAM and SON seasons, the drought frequency accounted for more than $30 \%$. Meanwhile, the drought frequency in the 2015/2016 period covered all seasons, up to $41 \%$ in the severe class and $14 \%$ in extreme class.

In comparison between SPI and SPEI results, both indices showed almost similar results. Overall, SPEI resulted in a higher value of drought frequency. The differences were mostly identified in strong and very strong El Niño periods.

\section{c. Spatiotemporal Drought Distribution}

Drought is a phenomenon that occurs in a wide area. Spatial drought analysis was carried out to identify El Niño's effect on the western Timor area. We visualized monthly drought class distribution in spatial for both indices, then compared them between normal and El Niño years, represented by 2004 and 2015 (Figure 3). In a normal situation, drought class was only identified along the north coast of the study area from October to January (Figure $3 a$ and $3 c$ ).

The other months were dominated by the normal class as shown by green area. In 2015, El Niño affected the widened drought area for the last 5 months of the year (Figure $3 b$ and $3 d$ ). The specific area in which drought was firstly initiated (in August) was the western part of the study area. The drought classes then spread and almost covered all parts of the study area for the next 3 months (September-November). Since the year 2015 was classi-fied as a very strong El Niño period, some parts expe-rienced extreme drought class during the SON season.

(b) SPI, 2015
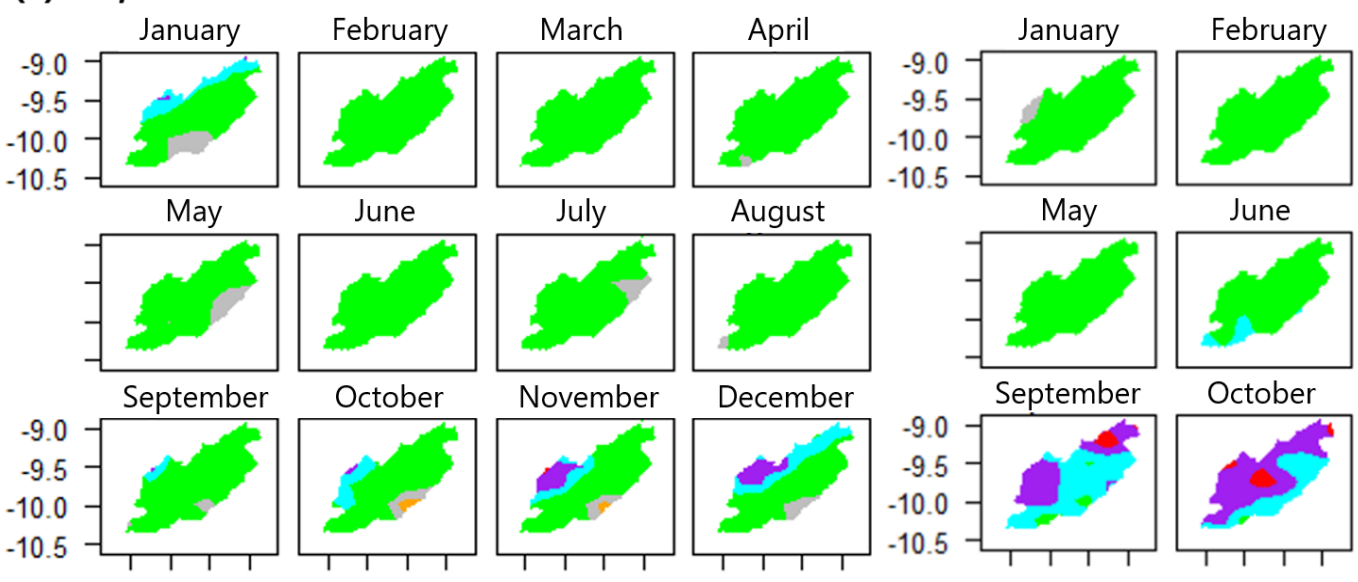

123.5124 .5
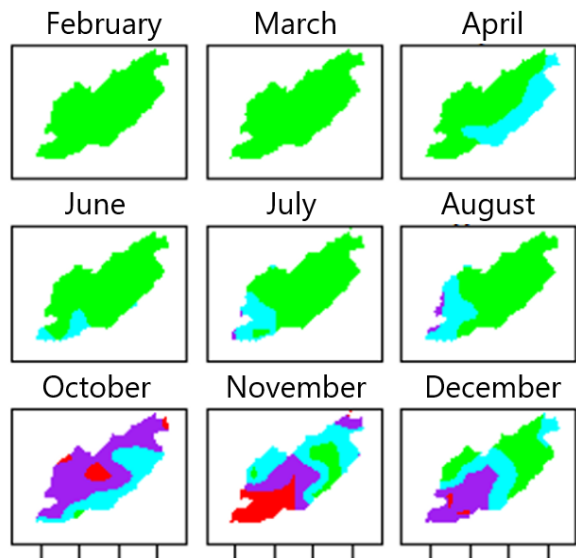

August

$$
123.5124 .5
$$

123.5124 .5

(c) SPEI, 2004
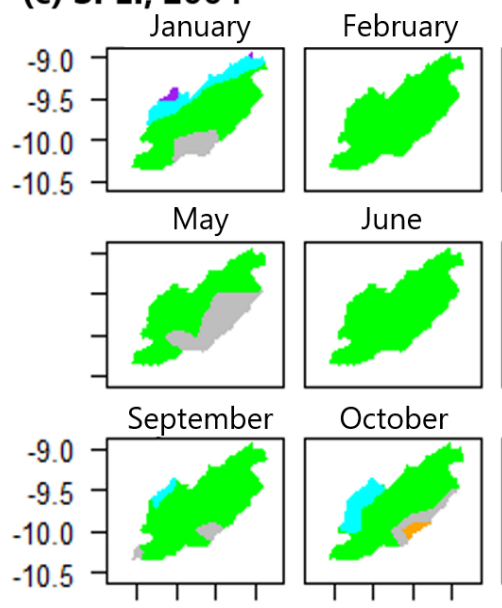

123.5124 .5

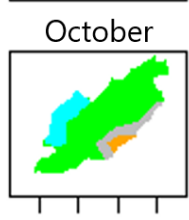

November

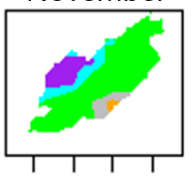

123.5124 .5
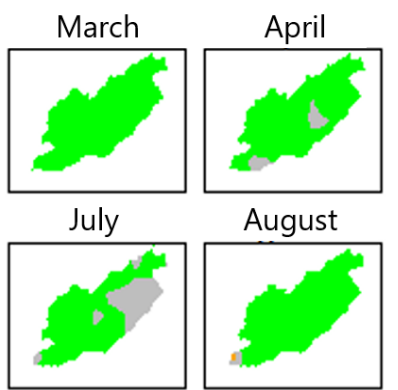

(d) SPEI, 2015
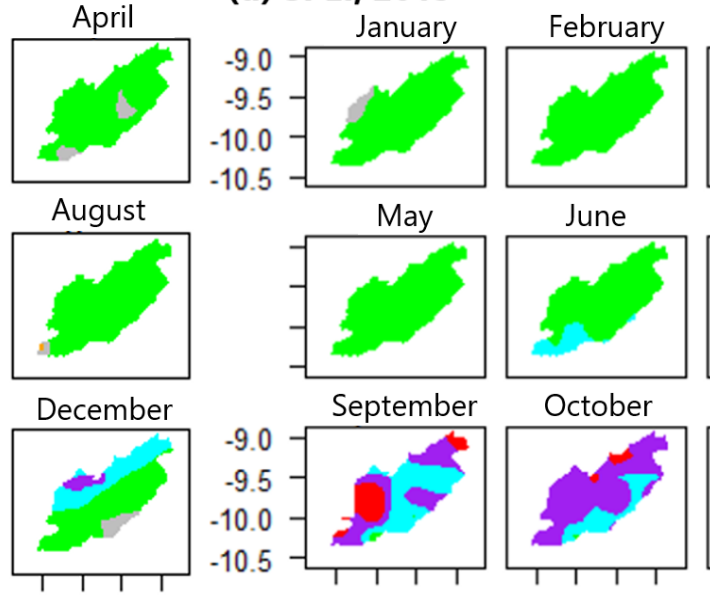

Index value
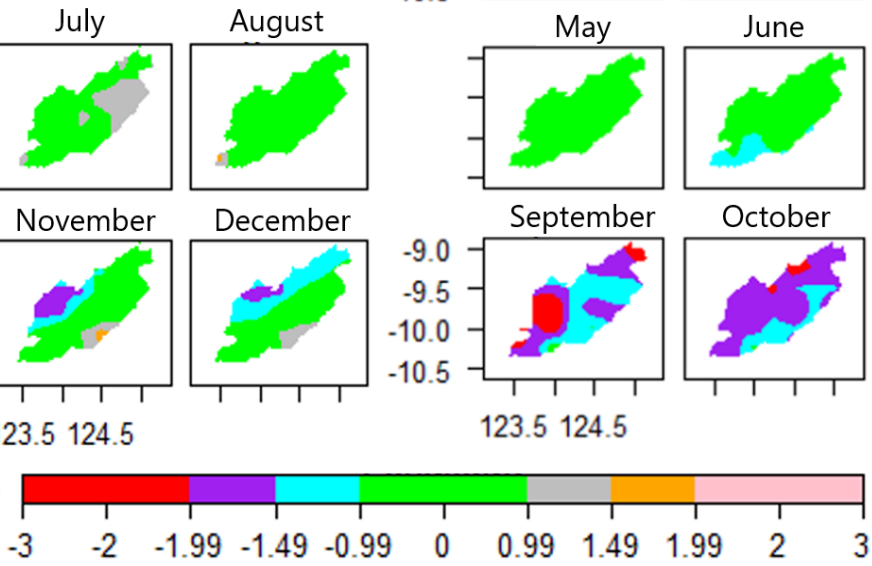

123.5124 .5

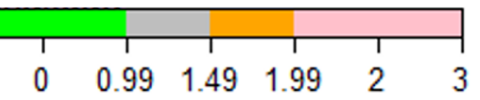

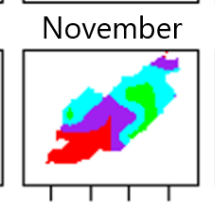

123.5124 .5

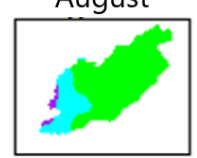

December
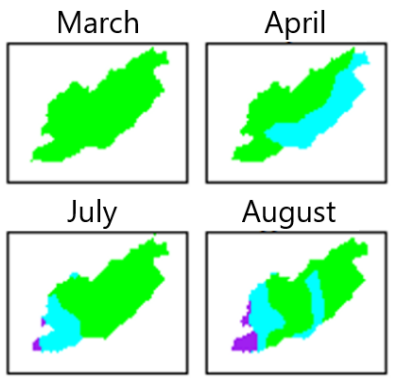

August

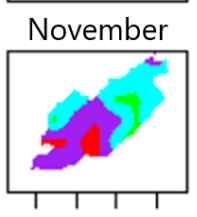

123.5124 .5
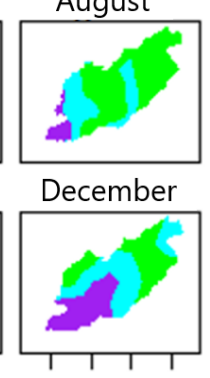

Figure 3. Spatial comparison of drought class distribution between normal (2004) and El Niño year (2015) based on Standardized Precipitation Index (SPI) and Standardized Precipitation Evapotranspiration Index (SPEI) in western Timor. 

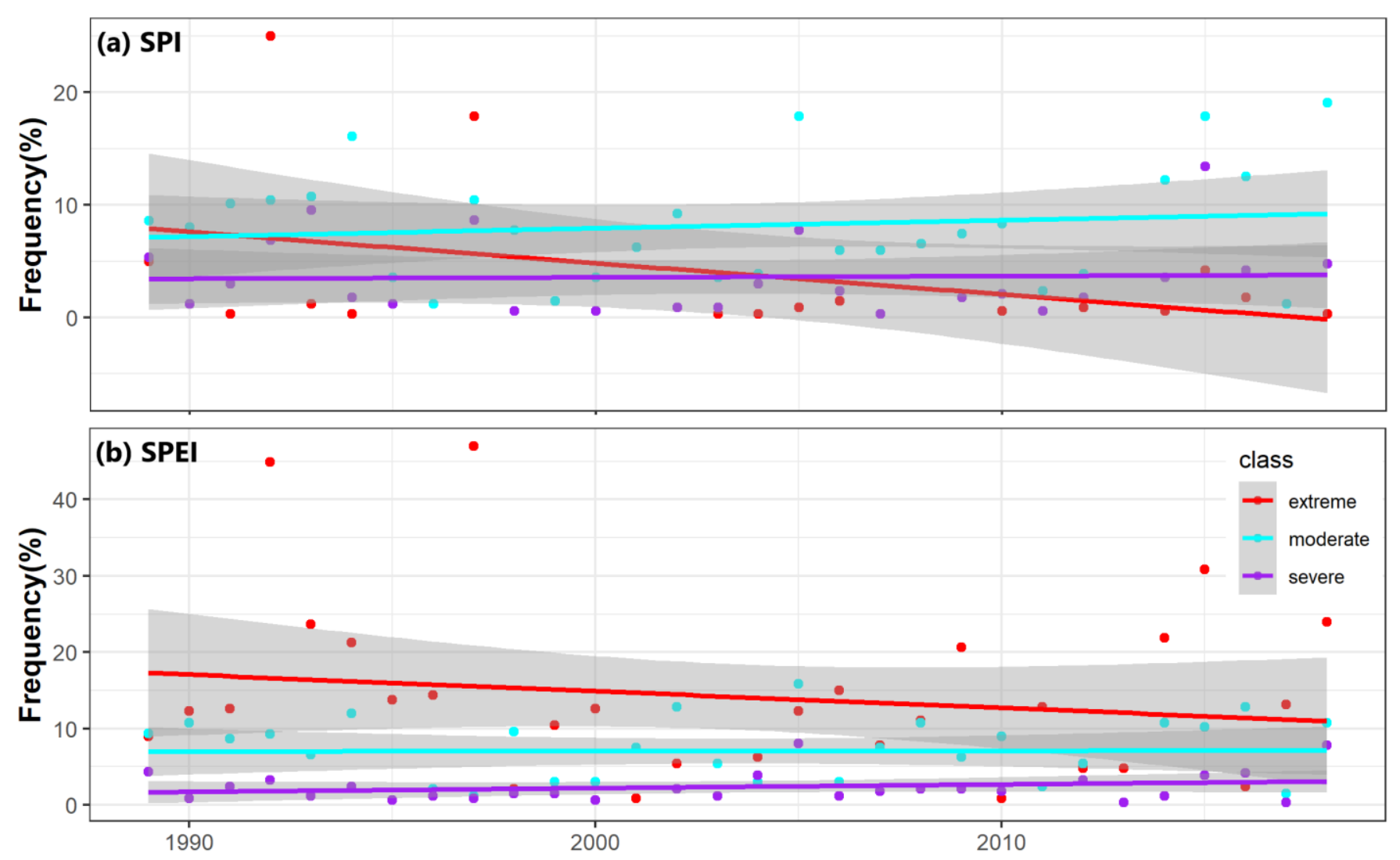

Figure 4. Drought trend based on annual drought class frequency calculated using: (a) Standardized Precipitation Index (SPI) and (b) Standardized Precipitation Evapotranspiration Index (SPEI) in western Timor during the period 1989-2018.

In comparison between the two drought indices, SPI and SPEI showed the same distribution pattern for each class in a normal year. The same results also showed in DJF, MAM, and JJA seasons 2015. Yet, there were different drought class patterns distributed in the SON season.

In September, SPEI depicted a wide area of extreme class in the western part, which was classified as a severe class in SPI. Based on SPI, in this month, western Timor was dominated by moderate drought class. On contrary, the spatial SPI for October pictured the extreme drought class in the middle of western Timor, which was categorized as severe drought in SPEI result. Meanwhile, in November, the SPI result showed that the southwestern part of the study area fully belonged to the extreme class. Yet, in SPEI results, only small parts were included in the extreme class.

\section{Drought Trend}

The annual drought frequency was used to determine the shift of each class over the analysis period. Based on linear regression, extreme class consistently had a downtrend, while the moderate class had upward trends for both drought indices (Figure 4). In general, the trends showed by SPEI results had higher gradient values compared to SPI. The linear line of extreme class derived from SPEI resulted in a gradient value of $17 \%$ higher than SPI. Meanwhile, for the moderate class, the difference between SPEI and SPI gradient values was only about 0.01 . The severe drought class was the only class that had a different trend between SPI and SPEI. There was a positive trend for this class based on SPI, yet it had a negative trend according to SPEI.

\section{CONCLUSION}

Based on the historical data, the rainfall condition of western Timor followed a monsoonal pattern with strong dry season from April to November. Frequency of annual drought in moderate conditions around 10$26 \%$, while severe and extreme occurred with an average of $1-26 \%$. The results showed that the dynamics of drought proportion for each class was mostly influenced by El Niño events. Seasonally, stronger severity of El Niño not only increased the drought frequency in JJA season but also in other seasons. In El Niño year of 2015, drought was significantly covered most parts of study area during SON season, especially in the western part. Dry conditions increase in June, maximum in SeptemberNovember and decrease in December. Based on linear trend line, extreme drought consistently had a 
downtrend, while the moderate class had upward trends. Spatiotemporal drought analysis using SPI and SPEI showed similar patterns, SPEI detected a higher frequency of drought classes compared to SPI.

\section{ACKNOWLEDGEMENT}

The authors thank two anonymous reviewers for their valuable comments that greatly improved the manuscript.

\section{REFERENCES}

Bhunia, P., Das, P., Maiti, R., 2020. Meteorological Drought Study Through SPI in Three Drought Prone Districts of West Bengal, India. Earth Systems and Environment 4, 43-55. https://doi.org/10.1007/s41748-019-00137-6

Cunha, A.P.M.A., Tomasella, J., Ribeiro-Neto, G.G., Brown, M., Garcia, S.R., Brito, S.B., Carvalho, M.A., 2018. Changes in the spatial-temporal patterns of droughts in the Brazilian Northeast. Atmospheric Science Letters 19, e855. https://doi.org/10.1002/asl.855

Danandeh Mehr, A., Vaheddoost, B., 2020. Identification of the trends associated with the SPI and SPEI indices across Ankara, Turkey. Theoretical and Applied Climatology 139, 15311542. https://doi.org/10.1007/s00704-01903071-9

Edwards, B., Gray, M., Hunter, B., 2019. The social and economic impacts of drought. Australian Journal of Social Issues 54, 22-31. https://doi.org/10.1002/ajs4.52

Ferijal, T., Batelaan, O., Shanafield, M., 2021. Spatial and temporal variation in rainy season droughts in the Indonesian Maritime Continent. Journal of Hydrology 603, 126999. https://doi.org/10.1016/j.jhydrol.2021.126999

Fung, K.F., Huang, Y.F., Koo, C.H., 2020. Assessing drought conditions through temporal pattern, spatial characteristic and operational accuracy indicated by SPI and SPEI: case analysis for Peninsular Malaysia. Natural Hazards 103, 20712101. https://doi.org/10.1007/s11069-02004072-y

Gidey, E., Dikinya, O., Sebego, R., Segosebe, E., Zenebe, A., 2018. Modeling the Spatio-Temporal Meteorological Drought Characteristics Using the Standardized Precipitation Index (SPI) in Raya and Its Environs, Northern Ethiopia. Earth Systems and Environment 2, 281-292. https://doi.org/10.1007/s41748-018-0057-7

Guimarães Nobre, G., Muis, S., Veldkamp, T.I.E., Ward, P.J., 2019. Achieving the reduction of disaster risk by better predicting impacts of El Niño and La
Niña. Progress in Disaster Science 2, 100022. https://doi.org/10.1016/j.pdisas.2019.100022

Guo, Y., Huang, S., Huang, Q., Wang, H., Fang, W., Yang, Y., Wang, L., 2019. Assessing socioeconomic drought based on an improved Multivariate Standardized Reliability and Resilience Index. Journal of Hydrology 568, 904-918. https://doi.org/10.1016/j.jhydrol.2018.11.055

Hendrawan, I.G., Asai, K., Triwahyuni, A., Lestari, D.V., 2019. The interanual rainfall variability in Indonesia corresponding to El Niño Southern Oscillation and Indian Ocean Dipole. Acta Oceanologica Sinica 38, 57-66. https://doi.org/10.1007/s13131-019-1457-1

Kang, H., Sridhar, V., Mills, B.F., Hession, W.C., Ogejo, J.A. 2019. Economy-wide climate change impacts on green water droughts based on the hydrologic simulations. Agricultural Systems 171, 76-88. https://doi.org/10.1016/j.agsy.2019.01.006

Kurniadi, A., Weller, E., Min, S.-K., Seong, M.-G., 2021. Independent ENSO and IOD impacts on rainfall extremes over Indonesia. International Journal of Climatology 41, 3640-3656. https://doi.org/10.1002/joc.7040

Lestari, D.O., Sutriyono, E., Sabaruddin, Iskandar, I., 2018 Severe Drought Event in Indonesia Following 2015/16 El Niño/positive Indian Dipole Events. Journal of Physics: Conference Series 1011, 012040. https://doi.org/10.1088/17426596/1011/1/012040

Liu, S., Shi, H., Niu, J., Chen, J., Kuang, X., 2020. Assessing future socioeconomic drought events under a changing climate over the Pearl River basin in South China. Journal of Hydrology: Regional Studies 30, 100700. https://doi.org/10.1016/j.ejrh.2020.100700

McKee, T.B., Doesken, N.J., Kleist, J., 1993. The relationship of drought frequency and duration to time scales. Presented at the 8th Conference on Applied Climatology, California, 17-22 January 1993, pp. 179-184.

Nath, R., Nath, D., Li, Q., Chen, W., Cui, X., 2017. Impact of drought on agriculture in the Indo-Gangetic Plain, India. Advances in Atmospheric Sciences 34, 335-346. https://doi.org/10.1007/s00376016-6102-2

Nguyen, P.-L., Min, S.-K., Kim, Y.-H., 2021. Combined impacts of the El Niño-Southern Oscillation and Pacific Decadal Oscillation on global droughts assessed using the standardized precipitation evapotranspiration index. International Journal of Climatology 41, E1645-E1662. https://doi.org/10.1002/joc.6796 
Noorisameleh, Z., Gough, W.A., Mirza, M.M.Q., 2021. Persistence and spatial-temporal variability of drought severity in Iran. Environmental Science and Pollution Research 28, 48808-48822. https://doi.org/10.1007/s11356-021-14100-4

Pan, X., Chin, M., Ichoku, C.M., Field, R.D., 2018. Connecting Indonesian Fires and Drought With the Type of El Niño and Phase of the Indian Ocean Dipole During 1979-2016. Journal of Geophysical Research: Atmospheres 123, 79747988. https://doi.org/10.1029/2018JD028402

Pei, Z., Fang, S., Wang, L., Yang, W., 2020. Comparative Analysis of Drought Indicated by the SPI and SPEI at Various Timescales in Inner Mongolia, China. Water 12. https://doi.org/10.3390/w12071925

Polong, F., Chen, H., Sun, S., Ongoma, V., 2019. Temporal and spatial evolution of the standard precipitation evapotranspiration index (SPEI) in the Tana River Basin, Kenya. Theoretical and Applied Climatology 138, 777-792. https://doi.org/10.1007/s00704-019-02858-0

Potopová, V., Štěpánek, P., Zahradníček, P., Farda, A., Türkott, L., Soukup, J., 2018. Projected changes in the evolution of drought on various timescales over the Czech Republic according to EuroCORDEX models. International Journal of Climatology 38, e939-e954. https://doi.org/10.1002/joc.5421

Qutbudin, I., Shiru, M.S., Sharafati, A., Ahmed, K., AlAnsari, N., Yaseen, Z.M., Shahid, S., Wang, X., 2019. Seasonal Drought Pattern Changes Due to Climate Variability: Case Study in Afghanistan. Water 11. https://doi.org/10.3390/w11051096

$R$ Core Team, 2021. R: A language and environment for statistical computing. $R$ Foundation for Statistical Computing, Vienna, Austria.

Russo, A., Gouveia, C.M., Páscoa, P., DaCamara, C.C., Sousa, P.M., Trigo, R.M., 2017. Assessing the role of drought events on wildfires in the Iberian Peninsula. Agricultural and Forest Meteorology 237-238, 50-59. https://doi.org/10.1016/j.agrformet.2017.01.021

Sein, Z.M., Zhi, X., Ogou, F.K., Nooni, I.K., Lim Kam Sian, K.T.C., Gnitou, G.T., 2021. Spatio-Temporal Analysis of Drought Variability in Myanmar Based on the Standardized Precipitation Evapotranspiration Index (SPEI) and Its Impact on Crop Production. Agronomy 11. https://doi.org/10.3390/agronomy 11091691

Shiau, J.-T., 2020. Effects of Gamma-Distribution Variations on SPI-Based Stationary and Nonstationary Drought Analyses. Water Resources Management 34, 2081-2095. https://doi.org/10.1007/s11269-020-02548-x
Singh, R.M., Shukla, P., 2020. Drought Characterization Using Drought Indices and El Niño Effects. National Academy Science Letters 43, 339-342. https://doi.org/10.1007/s40009-019-00870-6

Supari, Tangang, F., Salimun, E., Aldrian, E., Sopaheluwakan, A., Juneng, L., 2018. ENSO modulation of seasonal rainfall and extremes in Indonesia. Climate Dynamics 51, 2559-2580. https://doi.org/10.1007/s00382-017-4028-8

Surmaini, E., Susanti, E., Sarvina, Y., Syahputra, M.R., 2018. Development of Early Detection Method for Drought and Flood on Rice Paddy. Agromet 32, https://doi.org/10.29244/j.agromet.32.2.81-92

Surmaini, E., Susanti, E., Syahputra, M.R., Hadi, T.W., 2019. Exploring Standardized Precipitation Index for predicting drought on rice paddies in Indonesia. IOP Conference Series: Earth and Environmental Science 303, 012027. https://doi.org/10.1088/17551315/303/1/012027

Svensson, C., Hannaford, J., Prosdocimi, I., 2017. Statistical distributions for monthly aggregations of precipitation and streamflow in drought indicator applications. Water Resources Research 53, 999-1018. https://doi.org/10.1002/2016WR019276

Tallar, R.Y., Dhian, B.A., 2021. A viable drought vulnerability index for outermost small islands in Indonesia. Groundwater for Sustainable Development 15, 100698. https://doi.org/10.1016/j.gsd.2021.100698

Taufik, M., Minasny, B., McBratney, A.B., Van Dam, J.C., Jones, P.D., Van Lanen, H.A.J., 2020. Humaninduced changes in Indonesian peatlands increase drought severity. Environmental Research Letters 15, 084013. https://doi.org/10.1088/1748-9326/ab96d4

Taufik, M., Torfs, P.J.J.F., Uijlenhoet, R., Jones, P.D., Murdiyarso, D., Van Lanen, H.A.J., 2017. Amplification of wildfire area burnt by hydrological drought in the humid tropics. Nature Climate Change 7, 428-431. https://doi.org/10.1038/nclimate3280

Tefera, A.S., Ayoade, J.O., Bello, N.J., 2019. Comparative analyses of SPI and SPEI as drought assessment tools in Tigray Region, Northern Ethiopia. SN Applied Sciences 1, 1265. https://doi.org/10.1007/s42452-019-1326-2

Thornthwaite, C.W., 1948. An approach toward a rational classification of climate. LWW.

Trajkovic, S., Gocic, M., Pongracz, R., Bartholy, J., 2019. Adjustment of Thornthwaite equation for estimating evapotranspiration in Vojvodina. 
Theoretical and Applied Climatology 138, 1231$1240 . \quad$ https://doi.org/10.1007/s00704-01902873-1

Van Loon, A.F., 2015. Hydrological drought explained. WIRES Water 2, 359-392. https://doi.org/10.1002/wat2.1085

Vicente-Serrano, S.M., Beguería, S., López-Moreno, J.I., 2010. A Multiscalar Drought Index Sensitive to Global Warming: The Standardized Precipitation Evapotranspiration Index. Journal of Climate 23, 1696-1718.

https://doi.org/10.1175/2009JCLI2909.1

Wang, H., Chen, Y., Pan, Y., Chen, Z., Ren, Z., 2019. Assessment of candidate distributions for SPI/SPEI and sensitivity of drought to climatic variables in China. International Journal of Climatology 39, 4392-4412. https://doi.org/10.1002/joc.6081

Wang, W., Wang, J., Romanowicz, R., 2021. Uncertainty in SPI Calculation and Its Impact on Drought Assessment in Different Climate Regions over
China. Journal of Hydrometeorology 22, 13691383. https://doi.org/10.1175/JHM-D-20-0256.1

Wang, Y., Quan, Q., Shen, B., 2019. Spatio-temporal variability of drought and effect of large scale climate in the source region of Yellow River. null 10, 678-698. https://doi.org/10.1080/19475705.2018.154182 7

Williamson, F., 2020. Responding to extremes: managing urban water scarcity in the late nineteenth-century Straits Settlements. Water History 12, 251-263. https://doi.org/10.1007/s12685-020-00260-6

Yao, N., Li, Y., Dong, Q., Li, L., Peng, L., Feng, H., 2020. Influence of the accuracy of reference crop evapotranspiration on drought monitoring using standardized precipitation evapotranspiration index in mainland China. Land Degradation \& Development 31, 266-282. https://doi.org/10.1002/ldr.3447 